Scientific Electronic Archives
Issue ID: Sci. Elec. Arch. Vol. 15 (3)
March 2022
DOI: http://dx.doi.org/10.36560/15320221524
Article link: https://sea.ufr.edu.br/SEA/article/view/1524

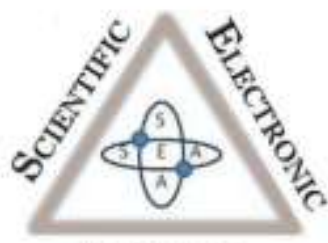

ARCHIVES

ISSN 2316-9281

\title{
Variation in wood properties of 26-year-old Handroantus impetiginosus cultivated in Luiz Antônio, SP
}

Camila Moura Santos

Instituto de Pesquisas Ambientais, Brasil

\author{
Diego Romeiro \\ Instituto de Pesquisas Ambientais, Brasil
}

Erick Phelipe Amorim

Programa de Pós-Graduação em Planejamento e Uso dos Recursos Renováveis Universidade Federal de São Carlos, Campus de Sorocaba, Brasil

\author{
Eduardo Luiz Longui \\ Instituto de Pesquisas Ambientais, Brasil \\ Corresponding author \\ Israel Luiz de Lima \\ Instituto de Pesquisas Ambientais, Brasil \\ israellima@sp.gov.br
}

\begin{abstract}
Provenance testing can provide information on silvicultural behavior and wood quality of species for selection of genetic material for different locations and conservation of the genetic base. The aim of this work was to study the longitudinal variation of basic density, volumetric shrinkage and microfibril angle of wood from two provenances (Assis and Bauru) of Handroantus impetiginosus planted in Luiz Antonio SP. After 26 years of planting, twelve trees were felled, six from each provenance. According to the results obtained, it could be concluded that the analysis of variance (ANOVA) showed that for the provenance there was a significant variation for the volumetric shrinkage of the wood and for basic wood density and microfibril angle the significance of variation did not occur. The basic wood density varied significantly between the different positions, at the height of the tree and for volumetric shrinkage, and for the microfibril angle it did not occur. There is a positive relationship between tree height and basic wood density of wood, for Assis and Bauru provenances.

Keywords: microfibril angle, basic density, volumetric shrinkage, longitudinal variation.
\end{abstract}

\section{Introduction}

Forestry is currently faced with major challenges related to aspects such as climate change, combating desertification, biodiversity conservation, soil and water. At the same time, issues of profitability and economic efficiency are also important. Some challenges posed in forestry involve choosing an adequate treatment method and combining forestry production with other benefits and ecosystem services.

In this sense, reconciling the economy with ecology, the combination of environmental, social and economic aspects presents great relevance to forestry, in order to contribute to sustainable development, i.e. where the forestry of native species is mainly oriented towards different uses and functions of forest settlement is also a generator of new activities, jobs and income, contributing to the development of local communities and the country in general. (Piña-Rodrigues and Silva, 2021).

To remedy the lack of or obstacles in the use of native species, the Brazilian industry in the timber sector has been using, on a large scale, logs of trees of the genus Pinus and Eucalyptus coming from reforestation as raw material for certain purposes. However, the use of native species from reforestation can also be another viable alternative, 
to be used by the Brazilian market. One of the native species with potential for use in reforestation is the Handroantus impetiginosus, which has been highlighted for its survival and productivity in pure plantations, being seen as a great potential for consumption and wood production. (Carvalho, 2003).

Handroantus impetiginosus can be planted in full sun, in pure planting, with satisfactory development when planted in fertile soils, but with inadequate form. The growth of this species in pure planting is considered slow to moderate, in mixed planting associated with pioneer and secondary species, it aims to improve the shape of the shaft. (Carvalho, 2003). Handroantus impetiginosus is a species that presents an excellent wood quality, malleable, resistant, with apparent density of 0.90 to 1.07 g.cm 3 at $15 \%$ moisture, basic density of 0.79 g.cm 3, core color brown and brownish-brown sapwood, the heartwood is little different from the sapwood, being considered as legal or quality and used for various noble purposes, furniture and civil and naval construction (Carvalho, 2003; Paula and Alves, 2007).

Among the parameters for evaluating the quality of wood for commercial use, we have the basic density, the volumetric shrinkage and the microfibril angle, and it is very important to know the variations and relationships between these wood properties.

The higher basic density wood and lower microfibril angle make the trees more resistant to breakage caused by the action of winds, therefore, they are more suitable for areas with a high incidence of wind (Zanuncio et al., 2017). It is possible to estimate the microfibril angle using the basic density and fiber length, making it more practical to determine the variation of this important characteristic of the cell wall and thus make the wood more suitable for its rational and sustainable use (Melo et al., 2018)

Many of the variations that occur in paper quality can be explained mainly by the basic density and angle of the wood's microfibril (Downes et al., 2003). The trunk diameter of trees has an influence on the microfibril angle, and trees with larger diameters have a tendency to present higher values of the microfibril angle (Tienne et al., 2009).

The microfibril angle partially controls the increase and/or decrease of the tensile growth stress, whereas cellulose content does not participate. (Shirai et al., 2015).

In this context, the present work aims to evaluate the longitudinal variation of basic density, volumetric shrinkage and microfibril angle in populations of Handroantus impetiginosus from two provenances.

\section{Materials and Methods}

Location and collection of samples

The study was carried out in an experimental plantation of Handroantus impetiginosus, located in the municipality of Luiz
Antônio, SP. The area is located at coordinates $21^{\circ}$ $40^{\prime} \mathrm{S}, 47^{\circ} 49^{\prime} \mathrm{W}$ with an altitude of $550 \mathrm{~m}$ above sea level. The relief has an inclination around $5 \%$, and the soil is of the Latosol Roxo type (Santos et al., 2018). It has a Köppen Aw climate classification, with an average annual temperature of $21.7^{\circ} \mathrm{C}$, maximum of $28.2^{\circ} \mathrm{C}$ and minimum of $15.2^{\circ} \mathrm{C}$. The average annual precipitation is $1516 \mathrm{~mm}$, with a minimum of $26.6 \mathrm{~mm}$ and a maximum of $273.6 \mathrm{~mm}$ (Flores et al., 2016).

The planting of Handroantus impetiginosus consisted of two populations from different provenances, one from Bauru SP and the other from Assis SP, and at 26 years of planting, the diameter at breast height $(\mathrm{DBH})$ was measured and 12 trees were selected. according to the DBH class, with 6 from each provenance (Table 1).

From the 12 selected trees, discs $5 \mathrm{~cm}$ thick at the base, $1.0 \mathrm{~m}, 2.0 \mathrm{~m}$ and $3 \mathrm{~m}$ from the height of each tree are removed. The sampled discs were used to study the physical properties and determine the microfibril angle of the wood. It was sampled, up to a height of $3 \mathrm{~m}$, in the tree. This sampling, only from this part of the tree, is justified because the $\mathrm{DBH}$ of the selected trees have an average value of around 8-15 cm, which makes it difficult to sample above $3 \mathrm{~m}$ in height, as the diameters would be even smaller (Table 1)

Table 1. Average values of DBHs and total heights of the trees of 26-year-old Handroantus impetiginosus trees according to the provenance.

\begin{tabular}{ccc}
\hline \multicolumn{3}{c}{ Assis } \\
\hline Tree & DBH $(\mathrm{cm})$ & Height $(\mathrm{m})$ \\
1 & 10.50 & 12.40 \\
2 & 9.50 & 8.10 \\
3 & 8.00 & 7.90 \\
4 & 9.50 & 13.74 \\
5 & 10.50 & 12.60 \\
6 & 12.00 & 12.65 \\
\hline Mean & 10.00 & 11.23 \\
\hline Tree & Bauru & \\
1 & 13.50 & Height $(\mathrm{m})$ \\
2 & 15.00 & 15.18 \\
3 & 14.00 & 14.35 \\
4 & 15.00 & 14.75 \\
5 & 13.50 & 15.30 \\
6 & 11.00 & 14.47 \\
\hline Mean & 13.67 & 9.55 \\
\hline & & 13.93 \\
\hline
\end{tabular}

Basic density (BD)

To obtain the basic density, a wedge of the sampled discs was used and the hydrostatic balance method according to NBR 11941 (ABNT, 2003) was used. 
Volumetric shrinkage $\left(\varepsilon_{v}\right)$

The volumetric shrinkage was obtained with the specimens of $2 \mathrm{~cm} \times 2 \mathrm{~cm} \times 3 \mathrm{~cm}$, (radial, tangential and longitudinal) removed from the discs, and determined according to the standard NBR 7190 (ABNT, 1979).

\section{Determination of the Microfibril Angle (MFA)}

From the discs obtained at different heights of the trees, blocks of $1 \times 1 \mathrm{~cm}$ were removed, in the intermediate position (between the pith and the bark), along the rays. These blocks were saturated in water and cut tangentially into thin sections $(<10 \mu \mathrm{m}$ thick) in a sliding microtome and according to the methodology of Leney (1981), the sections were placed in a maceration solution of 44 parts of acetic acid and 56 parts of $30 \%$ hydrogen peroxide, baked for 12 hours at $60^{\circ} \mathrm{C}$.

They were then washed in distilled water and provisional slides were prepared for measuring the angle of microfibrils (MFA). The angles were determined using the technique of polarized light microscopy under a microscope equipped with a rotating table graduated from $0^{\circ}$ to $360^{\circ}$. The blade is placed on the table, causing the fibers to stand upright.

Then, the table is turned clockwise until the sample reaches the maximum extinction position, that is, the color of the fiber background becomes darker. The difference in the angles of these two positions describes the microfibrillar angle.

\section{Statistical analysis}

The homogeneity of variance test was initially carried out using the Hartley test and, subsequently, the $\mathrm{F}$ test of analysis of variance according to a randomized block experimental design. Tukey's test for significant differences between means was used whenever the $F$ test detected at least one difference between treatments at the $5 \%$ level of significance.

The analysis of the relationship between the variables was performed using Pearson's correlation and, subsequently, the regression equations that best represented the significant correlations were obtained. In the data analysis, procedures from the SAS statistical program were used (SAS, 1999).

\section{Results and Discussion}

The analysis of variance (ANOVA) showed that for the provenance there was a significant variation for the volumetric shrinkage of wood $\left(\varepsilon_{v}\right)$, however it did not occur for the basic density (BD) and microfibril angle (MFA) (Table 2) The basic wood density varied significantly between the different positions, in the height of the tree, the same did not occur for the volumetric shrinkage and the microfibril angle (Table 2). It can also be seen that there were no significant interactions between the provenance and height of the tree variables, that is, there were no dependencies between these two factors (Table 2).

Table 2. Analysis of variance for basic density (BD), volumetric shrinkage $\left(\varepsilon_{v}\right)$ and microfibril angle (MFA), in according to the provenance and tree height of 26-year-old Handroantus impetiginosus.

\begin{tabular}{ccccc}
\hline \multirow{2}{*}{ Sources of variation } & Degrees of freedom & \multicolumn{3}{c}{ Mean square } \\
\cline { 3 - 5 } & & $\left(\mathrm{g} . \mathrm{cm}^{-3}\right)$ & $\varepsilon_{\mathrm{v}}$ & $\begin{array}{c}\text { MFA } \\
\left(\frac{0}{)}\right)\end{array}$ \\
\hline Provenance (P) & 1 & $0.0035^{\text {n.s. }}$ & 69.91 & $1.78^{\text {n.s. }}$ \\
Axial position (AP) & 3 & $0.0157^{\text {x. }}$ & $4.83^{\text {n.s. }}$ & $0.39^{\text {n.s. }}$ \\
P x AP & 3 & $0.005^{\text {n.s. }}$ & $21.71^{\text {n.s. }}$ & $0.82^{\text {n.s. }}$ \\
Residual & 40 & 0.0013 & 14.98 & 0.96 \\
Mean & & 0.69 & 14.35 & 9.99 \\
CVe $(\%)$ & 5.22 & 26.98 & 9.81 \\
\hline
\end{tabular}

n.s. $=$ not significant, ${ }^{*}=$ significant at $5 \%$ probability of error, ${ }^{\star *}=$ significant at $1 \%$ probability of error e $\mathrm{CV}_{\mathrm{e}}=\mathrm{coefficient}$ of experimental variation.

The mean values obtained for basic density (BD), volumetric shrinkage $\left(\varepsilon_{v}\right)$ and microfibril angle (MFA) were $0.69 \mathrm{~g} / \mathrm{cm}^{3} ; 14.35 \%$ and $9.99^{\circ}$, respectively (Table 2). Values of $0.89{\mathrm{~g} . \mathrm{cm}^{-3}}^{-3}$ for basic density and $0.94 \mathrm{~g} . \mathrm{cm}^{-3}$ and specific density were observed for $H$. impetiginosus by Paula and Costa (2011) and Paes et al. (2002). Volumetric shrinkage of $(10.9 \%)$ was found by (Mainieri and Chimelo, 1989), for $H$. impetiginosus, a value that is lower than that observed in this work. For the MFA in populations of Eucalyptus urophilla, Eucalyptus grandis and Eucalytus pellita, the mean value was $9.2^{\circ}, 10^{\circ}$ and $11^{\circ}$, respectively (Prasetyo et al., 2017). These values are very close to the value obtained for $\mathrm{H}$. impetiginosus, it is also close to the value of $12.6^{\circ}$ obtained for Acacia mangium by (Lokmal and Mohd, 2017). The MFA generally found in angiosperms is below $20^{\circ}$ and does not show clear decreasing trends in mature and juvenile wood (Liu et al., 2020).

The Assis provenance presented a higher volumetric shrinkage value $(15.55 \%)$ than Bauru $(13.14 \%)$, and this difference was significant at the $5 \%$ level (Figure $1 \mathrm{~b}$ ). The fact that the basic density and the microfibril angle do not differ significantly between the sources may be an indication that these properties may be less controlled by genetic and environmental factors than the volumetric shrinkage. However, heritability estimates for wood density and MFA are considered more moderate (Hung et al. 2016).

In a clonal population of Eucalyptus grandis $\times$ Eucalyptus urophylla, it was found that the higher basic density and smaller microfibril angle make 
these trees more resistant to breakage caused by wind (Zanuncio et al., 2017). According to the values obtained from the basic density and MFA, this seems to be the case for $H$. impetiginosus, therefore, this species may be suitable for planting in areas with a high incidence of wind. In addition, species that have greater potential for wood production usually have a low MFA value and high wood density, which leads to high microfibril stiffness (Lundqvist et al., 2017).

The angle of microfibrils and wood density are related to tree growth and wood quality and this makes it possible to explore genetic improvement in wood growth and properties, and this result suggests that radial tree growth does not only integrate the effects of genetics and environment, but also reflects a large effect of growth ring age, and this may better describe the relationship between tree growth and wood properties (Fang et al., 2020).

In planting populations of clones of Eucalyptus urophilla $x$ Eucalyptus grandis, the microfibrillar angle varied as a function of spacing, with the highest values being found in plantations with a density of 1000 trees per hectare, thus, the spacing can be used to avoid undesirable effects caused by high MFA, which can be a silvicultural strategy to produce wood with low MFA (Tienne et al., 2009).
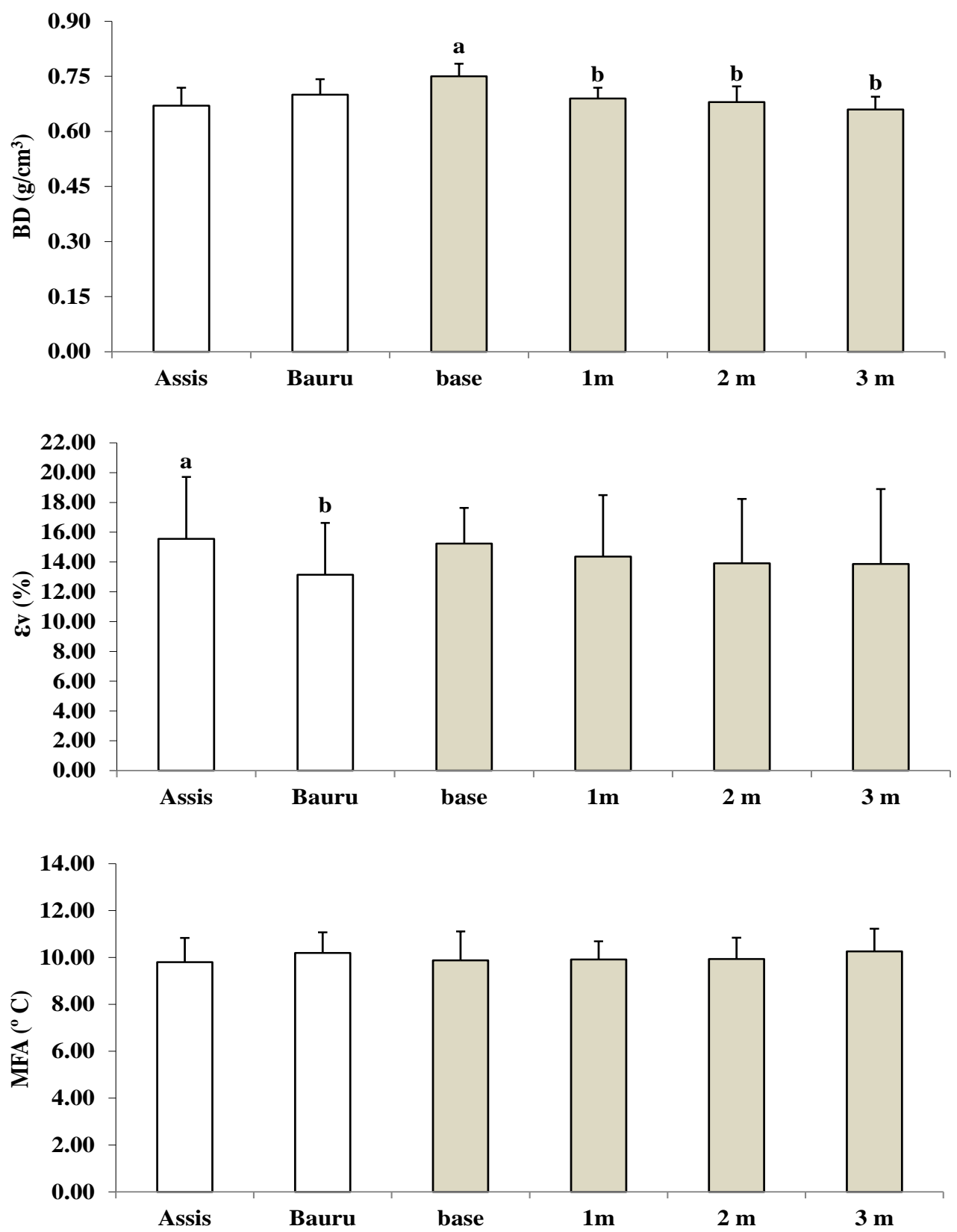

Figure 1. Basic density (BD), volumetric shrinkage $\left(\varepsilon_{v}\right)$ and microfibril angle (MFA) as a function of the provenance and height of 26-year-old Handroantus impetiginosus trees. Means followed by different letters (a or b) indicate statistical significance by t-test (between provenances) and Tukey's test (among axial position) $(p<0.05)$. 
The base of the tree presented a value $(0.75$ g. $\mathrm{cm}^{-3}$ ) of basic density, significantly higher than the other heights of the trees (Figure 1a). This result demonstrates that the basic density of $H$. impetiginosus may be more sensitive to the effects of tree height position than volumetric shrinkage and MFA, even for small heights. For a clonal population of Eucalyptus grandis x Eucalyptus camaldulensis it was found that the basic density and volumetric shrinkage decrease in the base-top direction of the tree and for MFA there is a marked decrease in the base up to $25 \%$ of the total height, and from that point onwards a more moderate decrease, up to the total height of the tree (Wessels et al., 2016).
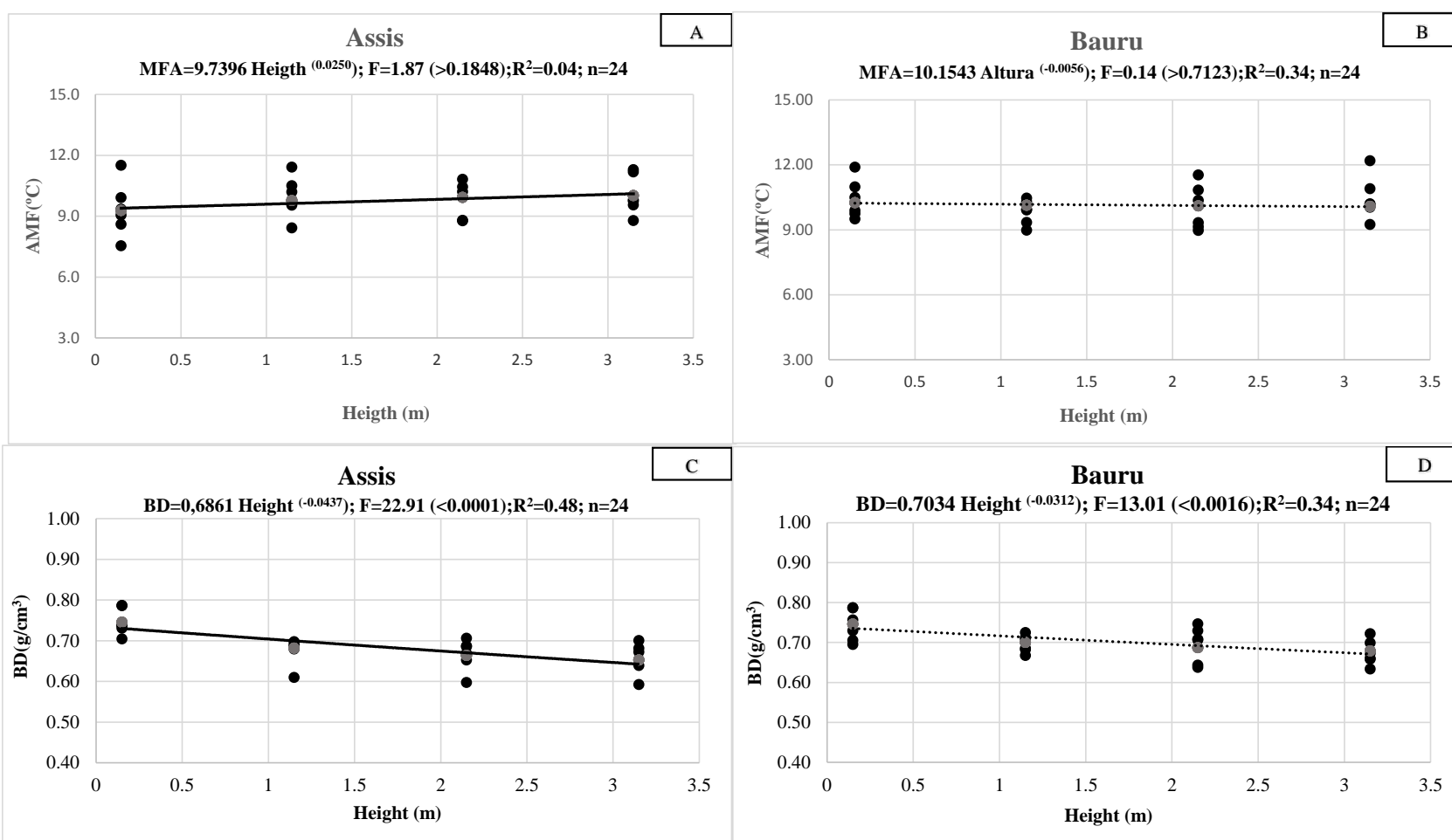

Assis
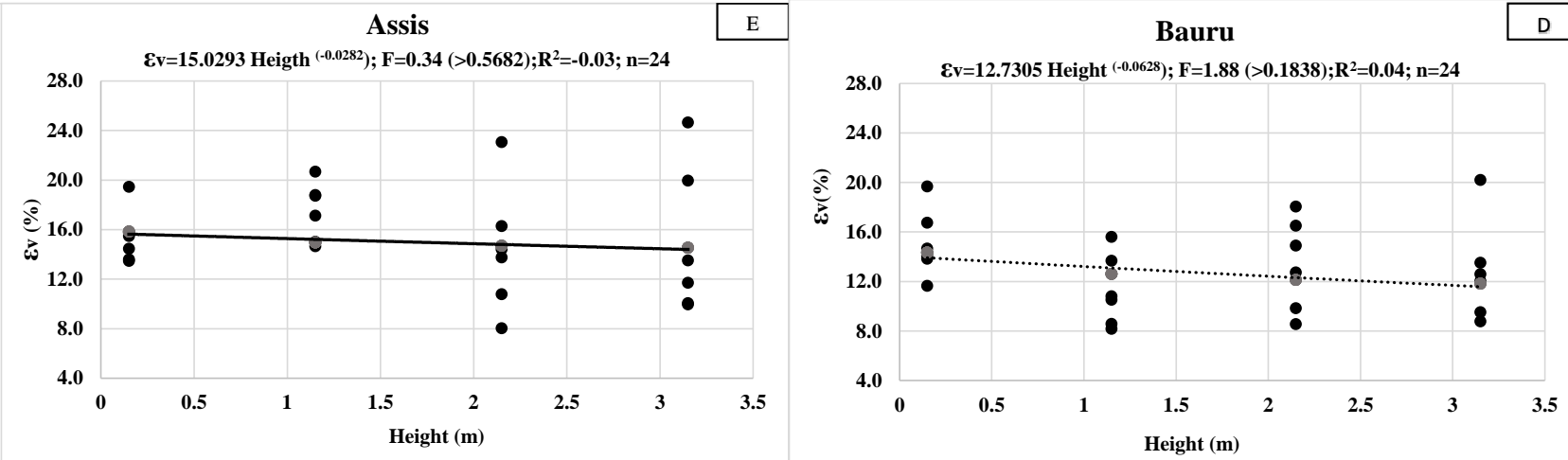

Figure 2. Relationship between the Basic density (BD), volumetric shrinkage $\left(\varepsilon_{\mathrm{v}}\right)$ and microfibril angle (MFA) with heigth of 26-year-old Handroantus impetiginosus trees by provenance.

The MFA was influenced by radial and longitudinal variation in Eucalyptus botryoides and Eucalyptus maculata (Knapic et al., 2018). Cell walls with very low MFA tend to have greater tangential retraction, whereas cell walls with very high MFA tend to have greater longitudinal retraction.

The microfibrils themselves may shrink slightly in the longitudinal direction, due to loss of water from the non-crystalline regions, causing some non-linearity in the volumetric shrinkage process (Donaldson et al., 2008).

However, in populations of Toona ciliata from three different locations, it was found, in relation to the results of the analyzes carried out in the base-top positions of the trees, for the microfibril angle that these differ from those found in the literature, as MFA from the three locations increased in the axial direction, in the bottom-top direction, and this can be explained by the silvicultural and environmental influences that may have occurred (Ribeiro et al., 2011).

To better understand the variations that occurred along the height of the tree, a study of the relationships between properties and longitudinal position separated by provenance was carried out.

In Figure 2 we have the regression models that best fit these variations. According to the polynomial regression model that was obtained, it 
was found that there was a trend of a significant decrease, in the base-top direction only for the basic density. The same result for the basic density was obtained by (Wessels et al., 2016).

For a clonal population of Populus deltoides, however, the best model obtained was the quadratic one, and there was still a tendency for basic density to increase with tree height, but the heights of the trees evaluated were greater than those in this article (Fang et al., 2020). For MFA and volumetric shrinkage, the regression coefficients were not significant (Figure 2). In Populus euramericana trees, the basic density and volumetric shrinkage of the wood at each height level decreased along the stem, from the base to the top, where the highest values of these properties were in the position of $5 \%$ of the total height of the tree. (Kord et al., 2010).

However, even if the regression coefficients between the characteristics are not significant, a possible simultaneous improvement can be achieved by selecting one or another characteristic, depending on the characteristic sought for improvement and its final use of the wood (Fang et al., 2020).

\section{Conclusions}

For the conditions of this research, it can be concluded for Handroantus impetiginosus wood that:

The basic density and microfibril angle of the wood were not influenced by the origin;

The volumetric shrinkage of the wood was influenced by its origin;

Basic wood density varied with tree height;

Volumetric shrinkage and microfibril angle did not vary significantly with tree height.

There is a positive relationship between tree height and basic wood density of Handroantus impetiginosus, for Assis and Bauru provenances.

\section{Acknowledgment}

The authors thank Sonia Regina Godoi Campião for laboratory assistance (Instituto de Pesquisas Ambientais - IPA). We are grateful to the FUNDAP (Fundação do Desenvolvimento Administrativo) for a grant to Camila Moura Santos.

\section{References}

ASSOCIAÇÃO BRASILEIRA DE NORMAS TÉCNICAS - ABNT. Normas Técnicas. NBR 7190: Projeto de Estruturas de Madeira. Rio de Janeiro, 1997, 107p.

ASSOCIAÇÃO BRASILEIRA DE NORMAS TÉCNICAS - ABNT. Normas Técnicas. NBR 11941: Densidade básica da madeira. Rio de Janeiro, 2003, $6 \mathrm{p}$.

CARVALHO, P.E.R. Espécies arbóreas brasileiras. Brasília: Embrapa Informação Tecnológica. Colombo: Embrapa Florestas, 2003. 1039 p.
DONALDSON, L. Microfibril angle: measurement, variation and relationships: a review. IAWA Journal. Vol. 29, p. 345-386, 2008.

DOWNES, G., EVANS, R., WIMMER, R., FRENCH, J., FARRINGTON, A., LOCK, P. Wood, pulp and handsheet relationships in plantation grown Eucalyptus globulus. Appita Journal. Vol. 56, p. 221228. 2003.

FANG, S., LIU, Y., YUE, J., TIAN, Y., XU, X. Assessments of growth performance, crown structure, stem form and wood property of introduced poplar clones: results from a long-term field experiment at a lowland site. Forest Ecology and Management. Vol. 479, p. 1-12, 2020.

FLORES, T.B., ALVARES, C.A., SOUZA, V.C., STAPE, J.L. Eucalyptus no Brasil: Zoneamento climático e guia para identificação. Piracicaba: IPEF, 2016. 448 p.

HUNG, T.D., BRAWNER, J.T., LEE, D.J., MEDER, R., DIETERS, M.J. Genetic variation in growth and wood-quality traits of Corymbia citriodora subsp. variegata across three sites in south-east Queensland, Australia. Southern Forests. Vol. 78. p. 225-239, 2016.

KNAPIC, S., GRAHN, T., LUNDQVIST, S.O., PEREIRA, $H$. Juvenile Wood Characterization of Eucalyptus botryoides and E. maculata by using SilviScan. BioResources. Vol. 13, p. 2342-2355, 2018.

KORD, B., KIALASHAKI, A., KORD, B. The withintree variation in wood density and shrinkage, and their relationship in Populus euramericana. Turkish Journal of Agriculture and Forestry. Vol. 34, p. 121126, 2010.

LENEY, L. A technique for measuring fibril angle using polarized light. Wood and Fiber Science. Vol. 13, p.13-16, 1981.

LIU, Y., ZHOU, L., ZHU, Y., LIU, S. Anatomical features and its radial variation among different Catalpa bungei clones. Forests. 2020, 11, 824. https://doi.org/10.3390/f11080824.

LOKMAL, N., Mohd Noor, A.G. (2017). Radial variation in microfibril angle of Acacia mangium. International Journal of Environmental \& Agriculture Research. Vol. 3, p. 35-42, 2017.

LUNDQVIST, S.O., GRAHN, T., OLSSON, L., SEIFERT, T. Comparison of wood, fibre and vessel properties of drought-tolerant eucalypts in South Africa. Southern Forests. Vol. 79, p. 215-225, 2017.

MAINIERI, C., CHIMELO, J.P. Fichas de Características das Madeiras Brasileiras. São Paulo: Instituto de Pesquisas Tecnológicas, 1989, 418p. 
MELO, L.E.D.L., GOULART, S.L., GUIMARÃES, B.M.R., GUIMARÃES NETO, R.M., SARTORI, C.J., LIMA, J.T. Prediction of microfibril angle for Eucalyptus microcorys wood by fiber length and basic density. Maderas. Ciencia y Tecnología, Vol. 20, p. 553-562, 2018.

PAES, J.B., MORAIS, V.D.M., LIMA, C.R. Resistência das madeiras de aroeira (Myracrodruon urundeuva), cássia (Senna siamea) e ipê (Tabebuia impetiginosa) a fungos e cupins xilófagos, em condições de laboratório. Floresta e Ambiente. Vol. 9, p. 135-144, 2002.

PAULA, J.E., ALVES J.L. 897 madeiras nativas do Brasil. Porto Alegre: Cinco Continentes, 2007. 279 p.

PAULA, J.E., COSTA, K. P. Densidade da madeira de 932 espécies nativas do Brasil. Porto Alegre: Cinco Continentes, 2011. 248p.

PIÑA-RODRIGUES, F.C.M., SILVA, J.M.S. Silvicultura Tropical: o potencial madeireiro e não madeireiro das espécies tropicais. 1ed. Sorocaba: Editora dos Autores, 2021, v. 1, 596 p.

PRASETYO, A., AISO, H., ISHIGURI, F., WAHYUDI, I., WIJAYA, I.P.G., OHSHIMA, J., YOKOTA, S. Variations on growth characteristics and wood properties of three Eucalyptus species planted for pulpwood in Indonesia. Tropics. Vol. 26 , p. 59-69, 2017.

RIBEIRO, A.O., MORI, F.A., MENDES, L.M. Características das dimensões das fibras e análise do ângulo microfibrilar de Toona ciliata cultivada em diferentes localidades. Floresta. Vol. 41, p. 47-56, 2011.

SANTOS, H.G., JACOMINE, P.K.T., ANJOS, L.H.C., OLIVEIRA, V.A., LUMBRERAS, J.F., COELHO, M.R., ALMEIDA, J.A., ARAUJO FILHO, J.C., OLIVEIRA, J.B., CUNHA, T.J.F. Sistema brasileiro de classificação de solos. 5. ed. Brasília: Embrapa, 2018. $356 p$.

S.A.S. Institute Inc. SAS Procedures Guide. Version 8 (TSMO). SAS Institute Inc. Cary, N.C., 27513, USA, 1999.

SHIRAI, T., YAMAMOTO, H., YOSHIDA, M., INATSUGU, M., KO, C., FUKUSHIMA, K., KULE, A. Eccentric growth and growth stress in inclined stems of Gnetum gnemon. IAWA Journal. Vol. 36, p. 365377, 2015.

TIENNE, D.L.C., OLIVEIRA, J.N., PALERMO, F.P. MOURA., SOUSA, J.S., LATORRACA, J.V.F. Influência do espaçamento no ângulo das microfibrilas e comprimento de fibras de clone de eucalipto. Revista Forestal Latinoamericana. Vol. 24, p. 67-83. 2009

WESSELS, C.B., CRAFFORD, P.L., DU TOIT, B., GRAHN, T., JOHANSSON, M., LUNDQVIST, S.O., SEIFERT, T. Variation in physical and mechanical properties from three drought tolerant Eucalyptus species grown on the dry west coast of Southern Africa. European Journal of Wood and Wood Products. Vol. 74, p. 563-575, 2016.

ZANUNCIO, A.J.V., CARVALHO, A.G., CARNEIRO, A.D. C.O., VALENZUELA, P., GACITÚA, W., LEITE, F.P., COLODETTE, J.L. Characterization of eucalyptus clones subject to wind damage. Pesquisa Agropecuária Brasileira. Vol. 52, p. 969976, 2017. 